Transport and Communications Science Journal

\title{
STATIC LOADING TESTS ON SMALL-SCALE PILE GROUPS
}

\section{Bach Vu Hoang Lan}

University of Architecture Ho Chi Minh City, No 196 Pasteur Street, Ward 6, District 3, Ho Chi Minh City, Vietnam

\section{ARTICLE INFO}

TYPE: Research Article

Received: 5/10/2020

Revised: 30/10/2020

Accepted: 6/11/2020

Published online: 25/01/2021

https://doi.org/10.47869/tcsj.72.1.10

* Corresponding author

Email: lan.bachvuhoang@uah.edu.vn; Tel: 0903696740

\begin{abstract}
More understanding of the performance of a group pile is very important in construction. In this paper, 36 small-scale model tests in soft clay were conducted to research the performances of pile groups under rigid caps. The parameters studied were the effect of pile length, pile spacing, and the number of piles in a group. The group piles consisted of 4,6 , and 9 circular model piles of $16 \mathrm{~mm}$ in outer diameter (D), while four kinds of the pile spacing between pile centers $3 ; 4 ; 5$; and 6 times of the diameter and three types of the embedded pile lengths: 20D; 25D; and 30D were used. For comparison, three single piles with the same diameter and length were also tested under the same condition. The experimental results were discussed based on the following 3 points of view: the pile group efficiency, the settlement ratio, load distribution per pile location in the group pile. All discussion suggested that the pile number and pile spacing in a pile group caused a remarkable interactional effect between piles, whereas the settlement ratios are significantly affected by the pile length. Besides, each pile in the group of $6 \mathrm{D}$ pile spacing behaved more individually.
\end{abstract}

Keywords: Pile groups, Static load test, Pile group efficiency, Settlement ratio, Load distribution per pile.

(C) 2021 University of Transport and Communications

\section{INTRODUCTION}

When piles in a group are placed with close space, the induced stresses and strains in the surrounding soil overlap, so their behavior becomes different from a single pile, which is working in the same conditions [1-12]. To understand the performance of a group pile, many model tests were conducted by previous researchers, such as T. Whitaker 1957 [11]; A,B. Vesic 1967 [10]; Y. Koizumi and K. Ito 1967 [5]; Kytiyodom P. et al. 2004 [7]; Zhang Y. et 
al. 2012 [12]; Adejumo T.W., and Boiko I.L. 2013 [1]; Goto S. et al. 2013 [4]; Patil J.D. et al. 2015 [9]; Zhijia You and Yulong Chen 2018 [6]; etc. Big-budget of making load tests on fullscale pile group at the site and the high variability of field conditions make them difficult for research aims. For those reasons, there are few in situ, full-scale pile group load tests reported in the literature, and most pile group tests were scaled down regardless of whether performed in the field or laboratory.

There is, however, a scarcity of available test data for performance pile groups in soft clay to assist in the understanding of factors that affect their behavior. The paper indicates and analyses the test results. Consideration is placed on the pile group efficiency and the settlement at working loads for the pile groups as compared to single piles. The measured axial load transfers along the piles in a group are compared with those of the single piles to determine the pile efficiencies and predict the settlement of a pile group.

\section{STATIC LOAD TESTS ON MODEL PILE GROUPS}

\subsection{Small-scale model of the pile groups}

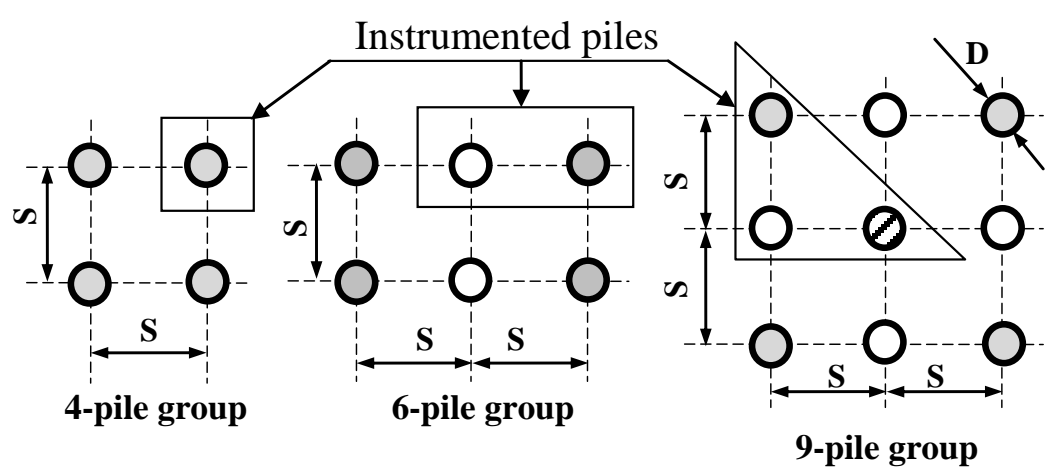

Note: Ocorner pile $\mathrm{O}$ Edge pile $\boldsymbol{O}$ Center pile

$\mathrm{D}=16 \mathrm{~mm}$ - Pile diameter; $\mathrm{S}$ - Pile spacing

Figure1. Configuration of the studied pile groups.

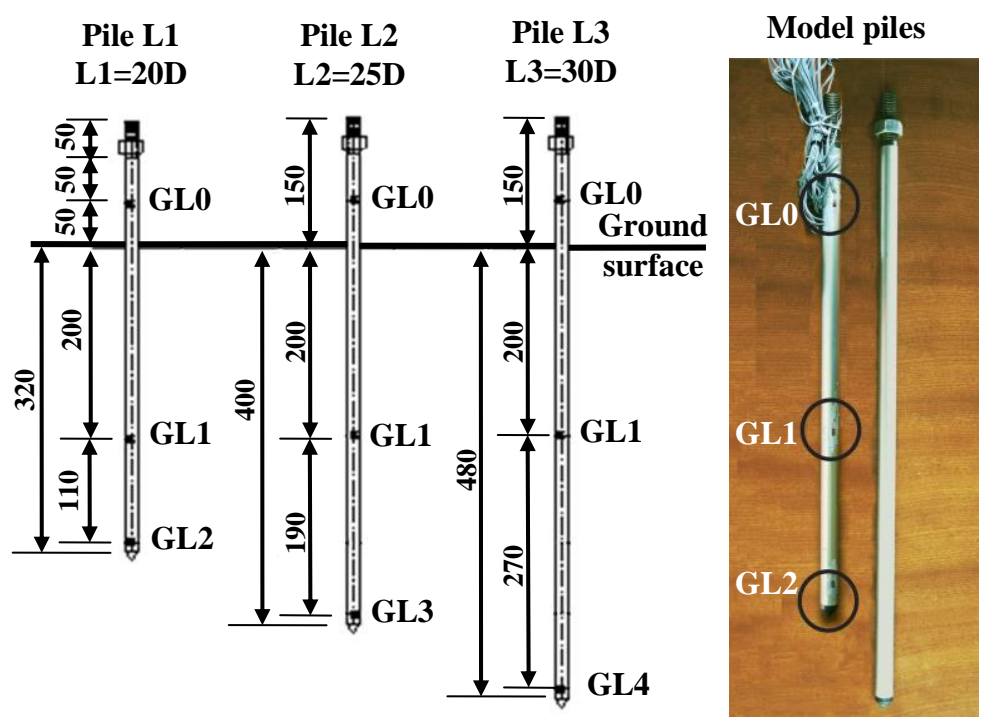

Figure 2. Details of the instrumented piles. 
The entire model piles are manufactured by aluminum pipes, which were of $D=16 \mathrm{~mm}$ outer diameter, $0.5 \mathrm{~mm}$ in thickness, and their elastic modulus $\mathrm{E}_{\mathrm{p}}=95.5 \mathrm{GPa}$. The static load tests are performed on three different configurations of the pile groups $2 \times 2,2 \times 3$, and $3 \times 3$ as shown in Fig.1. Four kinds of pile spacing $(S)$ in a group were used: $3 D=48 \mathrm{~mm}, 4 \mathrm{D}=64 \mathrm{~mm}$, $5 \mathrm{D}=80 \mathrm{~mm}$, and $6 \mathrm{D}=96 \mathrm{~mm}$. Three types of model piles, which consist of the initially embedded pile lengths of 320mm (L1=20D); $400 \mathrm{~mm}$ (L2=25D); and $480 \mathrm{~mm}$ (L3=30D), were put into the study.

All instrumented piles are attached strain gauges at three levels along the pile length, and in which the gauge level 0 (GL0) and the pile cap were located above the ground surface to evaluate the load distributions of each pile in a pile group (Fig.2).

\subsection{Experimental equipment and pile installation}
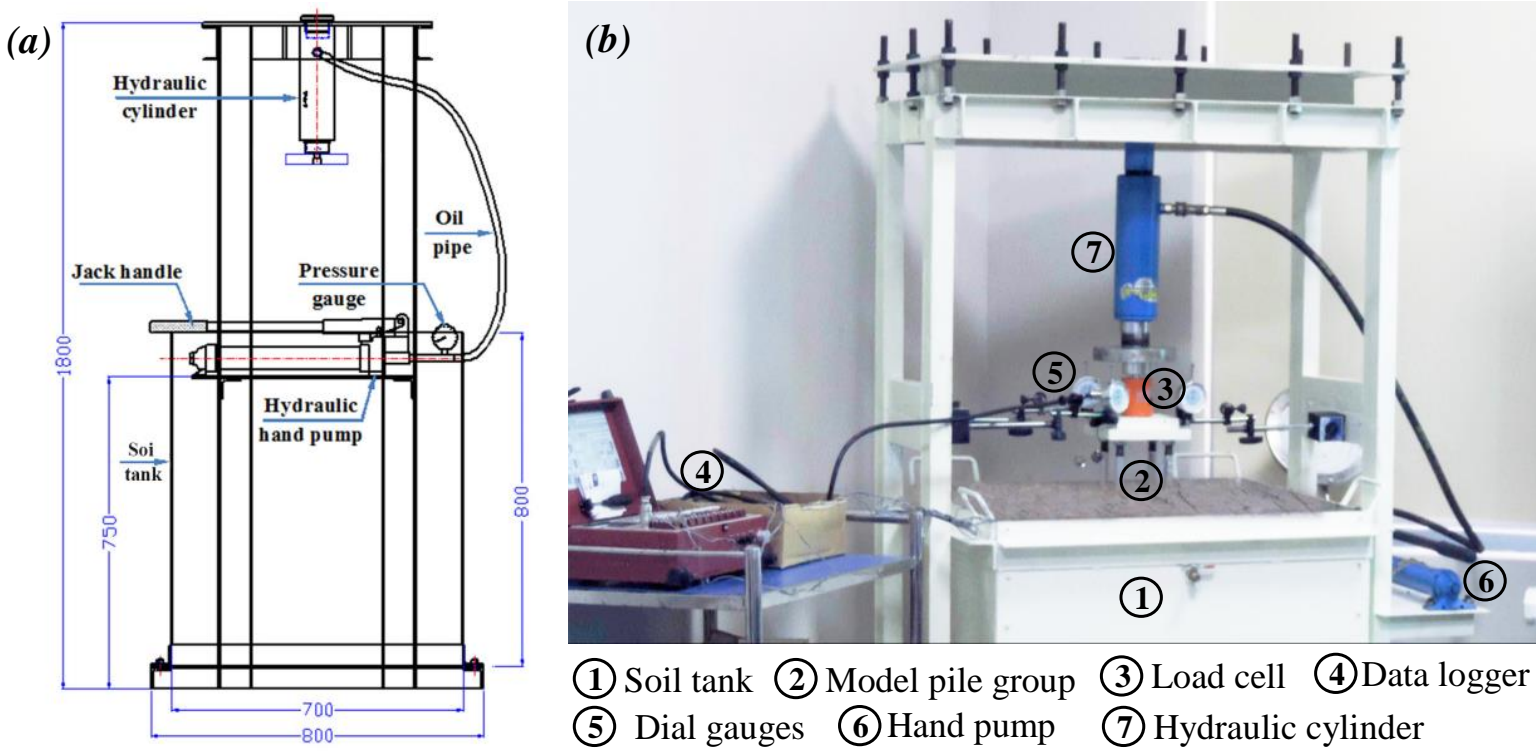

Figure 3. Side view of the testing equipment and experimental setup.

Clay soil sample obtained from a site in district 7, Ho Chi Minh City, Vietnam were used in this study. The soft clay was modelled with a liquid limit $\mathrm{w}_{\mathrm{L}}=56 \%$; plasticity index $\mathrm{I}_{\mathrm{L}}=31 \%$; moisture content $\mathrm{w}=50 \%$, and unit weight $\gamma=17 \mathrm{kN} / \mathrm{m}^{3}$. The clay samples were reconsolidated in the steel container with dimensions of $700 \times 700 \times 800(\mathrm{~mm})$ for length, width, and depth respectively. The size of the soil tank is chosen so that there is no interference between the container walls and the stress zones around the largest dimension of the 9-pile group. Fig. 3a illustrates the side view of the testing equipment, which is used for the static load tests.

Before the pile installation, a suitable model cap was placed fixedly over a pile group (Fig.4b), and then all together was driven into the soil bed. One day after completed pile installations, the static loading tests of the single pile or pile groups were performed to reach the plunging failures.

Settlements were measured at three locations on the upper surface of the cap using threedial gauges. The records from all dial gauges were considered to function satisfactorily and the average index was used representative of the pile group settlement. The axial loads 
transferred along the instrumented piles were measured by three levels of strain gauges, which were mounted outside these piles. Schematic arrangement of equipment for a model pile group testing is shown in Fig. 3 b.

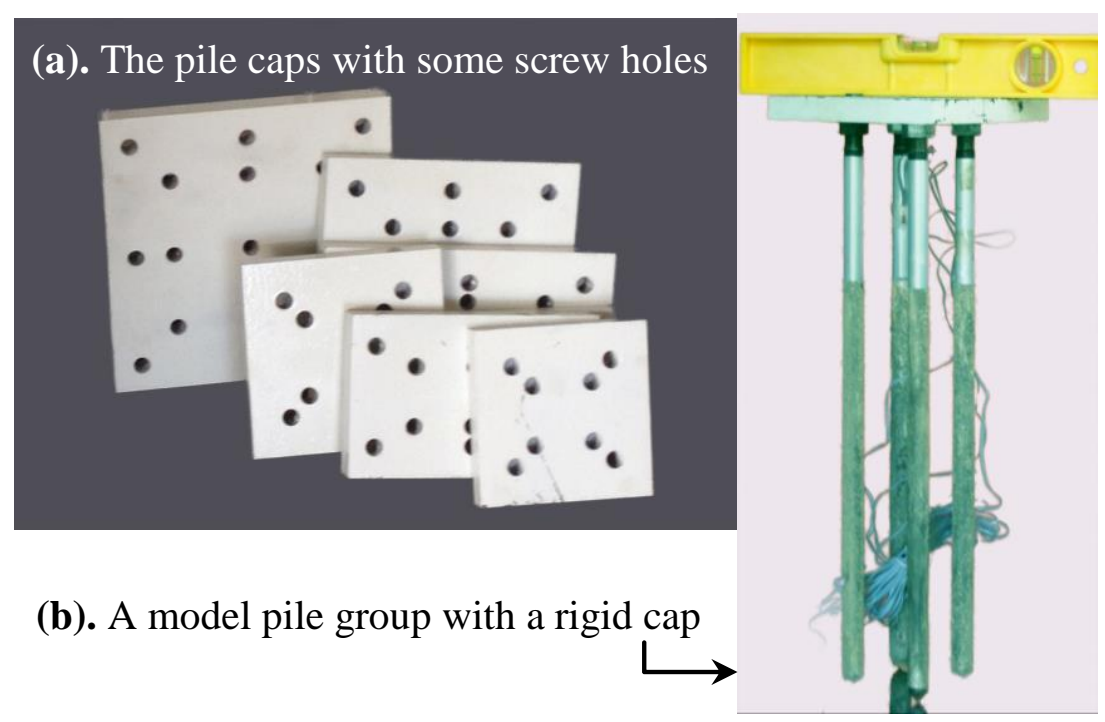

Figure 4. Details of the pile caps and a 4-pile group.

\subsection{Static load test program}

To ensure the accuracy of the strain data recording of the tested piles, avoiding errors due to creep phenomenon, the quick load test procedure was used to examine the behavior of all single piles and pile groups under static compressive loads. The load tests on three type lengths of the single piles are performed with 7 to 11 steps until obtaining the failure loads of $105 \mathrm{~N}, 135 \mathrm{~N}$, and $165 \mathrm{~N}$, respectively. In which, each load increment was about $15 \mathrm{~N}$, and was held constant for 5 minutes, except the maximum load level was kept until each pile reaching the stable state.

In the same way, the loading tests of 4-pile, 6-pile, and 9-pile groups were executed in 6 through 16 increment levels until obtaining the failure load of each group. Note that, the magnitudes of load increments depend on the number of piles in each group.

\section{MEASUREMENTS}

\subsection{Load versus settlement}

Because of space limitations, Fig.5 only shows the measured load versus settlement diagrams of three single piles and average load-settlement curves of 4-pile, 6-pile, and 9-pile groups, which have embedded pile length of 20D, 25D, and 30D, respectively. All load tests were done until reaching the plunging failures and their movements are in the range of 10.5 $\mathrm{mm}$ to $14.5 \mathrm{~mm}$. The maximum load and of the single piles, which are denoted SP-L1; SP-L2, and SP-L3, are measured about $105 \mathrm{~N}, 135 \mathrm{~N}$, and $165 \mathrm{~N}$ respectively, as displayed in Fig.3a.

Generally, the average load per pile in a group is less than the load on a single pile at the same settlement. Also, Figs.4b, 4c, and $4 d$ clearly show that the pile spacing significantly affected the load - settlement response, as a result, the bigger ultimate axial capacity of the pile group was caused by the larger pile spacing. 
Transport and Communications Science Journal, Vol. 72, Issue 1 (01/2021), 84-94

(a) Load of single pile (N)

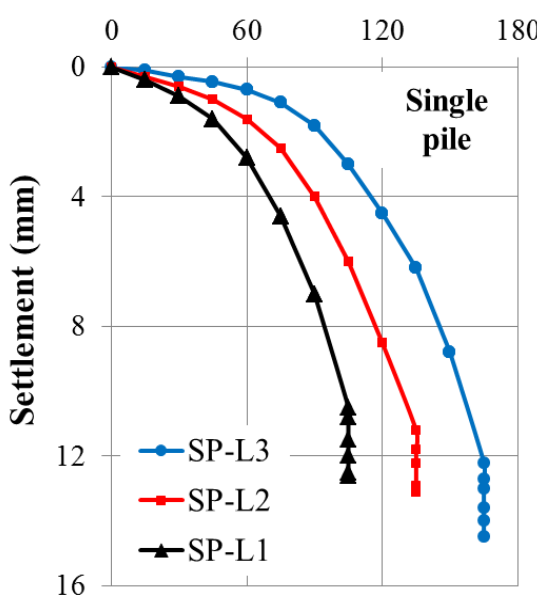

(c) Load of single pile (N)
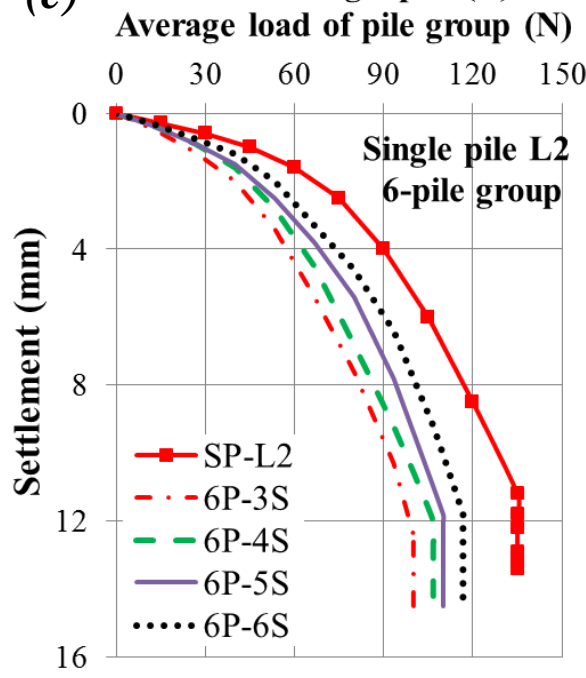

(b) Load of single pile (N) Average load of pile group $(\mathrm{N})$

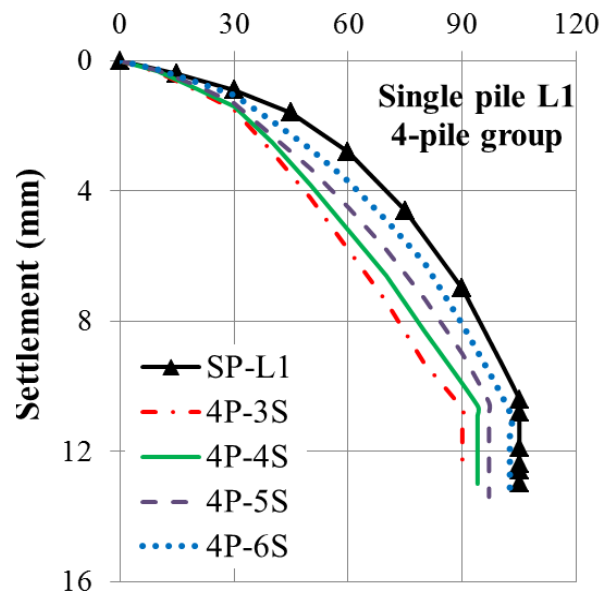

(d) Load of single pile (N) or

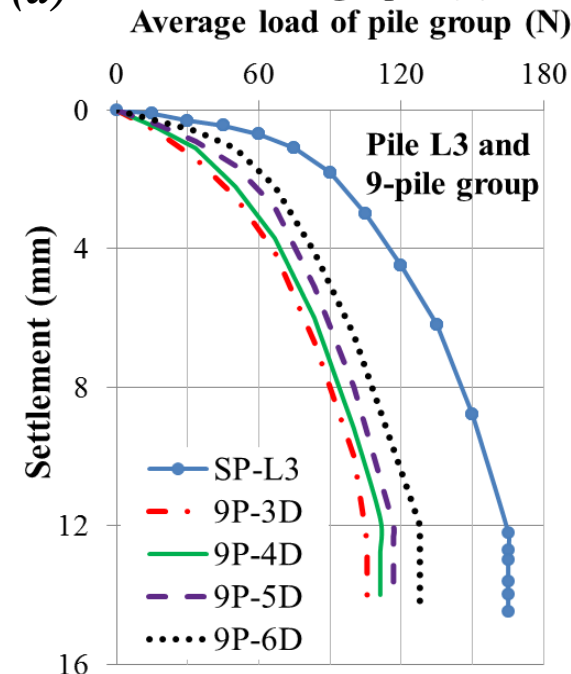

Figure 5. Load versus settlement of the single piles and the studied pile groups.

\subsection{Load versus strain}
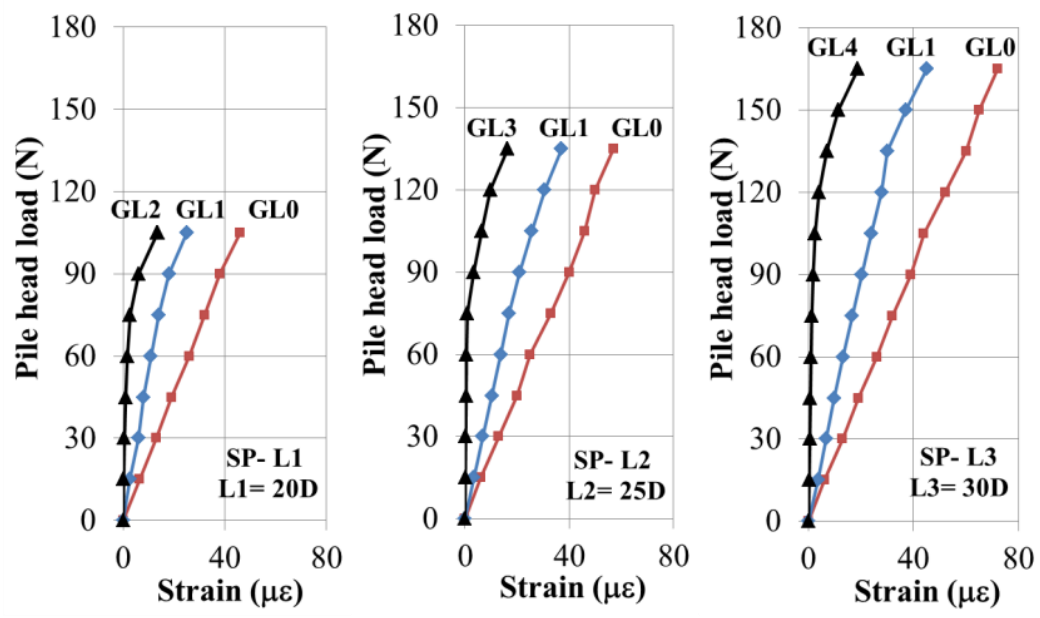

Figure 6. Load versus strain of the single piles. 
During static load tests, all strain gauges attached to the pile shaft were recorded. Fig.6 indicates the comparison of strain records at all gauge levels of the single piles. The loadstrain curves at the pile head level (GL0) of three piles are relatively linear; it shows that the pile material had to work in the elastic phase. However, the load - strain graphs of remaining levels (GL1, GL2, GL3, and GL4) are slightly curved, because they were affected by the friction forces between the pile shaft and surrounding soil.

Because of the huge data, the strain gage record of each pile in the investigated pile groups not show here.

\section{ANALYSIS OF LOAD TEST RESULTS}

\subsection{Pile group efficiency}

In general, the performance of a pile group is given by group efficiency $(\eta)$, and it is calculated by using the Eq.1:

$$
\eta=\frac{Q_{G}}{n m Q_{S}}
$$

Where: $Q_{G}$ and $Q_{S}$ are the bearing capacity of a pile group and a single pile, respectively; $m$ and $n$ are the row number, and the pile number in a row, respectively.

Besides that, Feld's rule is known that the simplest way to estimate the pile group efficiency. Feld 1943 [2] stated that the bearing capacity of each pile in a group is reduced by one-sixteenth (1/16) on account of an adjacent pile. On the other hand, the Converse-Labarre formula is one of the most commonly used to calculate group efficiency. According to Sayed M.S. et al. [2], in the group $m \times n$ piles, the group efficiency is expressed as:

$$
\eta=1-\frac{\Phi}{90}\left[\frac{(n-1) m+(m-1) n}{m \times n}\right]
$$

In which: $\Phi$ is the arc-tan of the ratio D/S (in degrees), $D$ is the pile diameter, and $S$ is the spacing between piles in a group;

The charts found experimentally in Fig.7 inform that the pile number is the most parameter affected on the group efficiency $(\eta)$, so for any spacing and length, the group efficiencies of 4-pile groups are always larger than those of 6-pile and 9-pile groups. Moreover, these curves show that the value of efficiency grows significantly with increase spacing between piles in a group. It is exciting to see that, the chart slopes of 4-pile groups are larger than those of 6-pile and 9-pile groups, it shows that the effect of spacing on group efficiency increases with decreasing in pile number. Furthermore, each diagram in Fig.7 presents that the value of $\eta$ does not change greatly within a pile group configuration when the pile length changing. For example, in 4-pile groups for 6D spacing, its efficiencies decrease slightly from 0.98 to 0.94 for 20D-length and 30D-length, respectively.

Besides, Fig.7 shows the comparison of efficiency calculated by the Converse-Labarre formulas, Feld's rule, and test results. Although Feld's rule does not consider the effect of the spacing and pile length on the efficiency value, the outcomes of this rule are quite similar to the corresponding results conducted by test data of the pile groups for 3D to 4D spacing. There is a suitable presentation between the efficiency magnitudes of the 6-pile groups 
computed by tests and those calculated by the Converse-Labarre formula. However, the group efficiencies of the 9-pile groups calculated by test data are significantly smaller than the corresponding value conducted by Eq.2 for any spacing and pile lengths. Additionally, in 4pile groups for spacing $3 \mathrm{D}$ to $5 \mathrm{D}$, the efficiency obtained by two methods is nearly the same, but for spacing $6 \mathrm{D}$ these values are totally different.
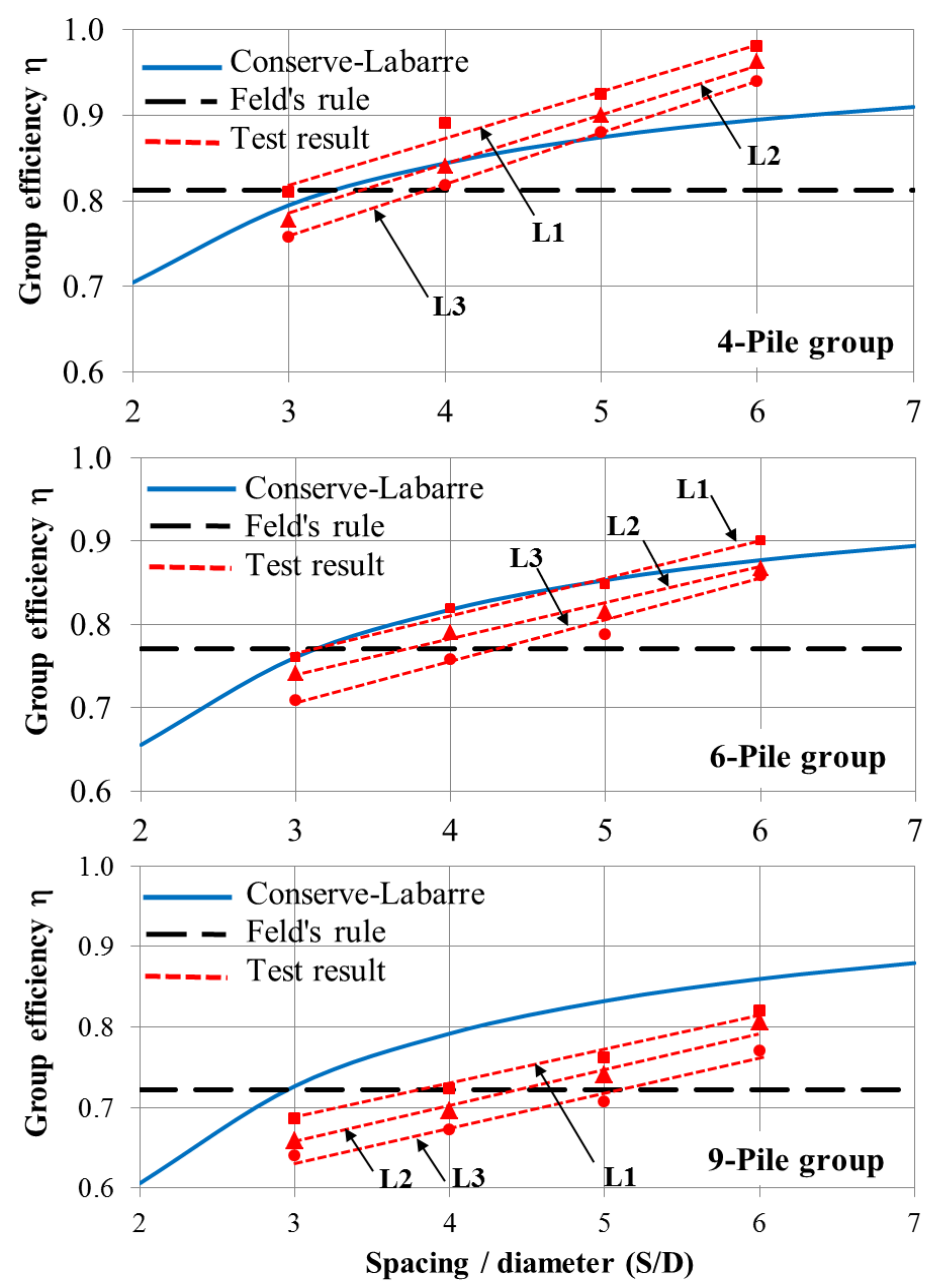

Figure 7. Comparison of group efficiency calculated by formulas and tested results.

\subsection{Group settlement ratio}

The performance of a pile group is not only evaluated by the group efficiency, but also by the group settlement ratio $\left(R_{S}\right)$. This ratio is determined by the proportion between the axial movement of a pile group and the corresponding value of a single pile subjected to the load equal to the average load per pile in the group. In other hands, Randolph and Clancy 1993[8] proposed the empirical expression to estimate the settlement ratio of a pile group:

$$
R_{S}=\sqrt{\frac{n m S}{L}}
$$

Where: $S$ is the pile spacing; $L$ is the embedded pile length; $m$ is the number of rows, and $n$ is the number of piles in a row. 
The settlement ratios obtained at the failure loads of all pile groups are shown in Fig.8. It clearly informs that, although having the same spacing and pile length, the values of these ratios grow markedly to the increasing of the pile number. For example, $\mathrm{R}_{S}=4$. 1 , occurring at the 9-pile group for 3D spacing and 30D pile length, whereas the corresponding value of the 4-pile group is only 2.7. Moreover, these graphs inform that the influence of the pile length on this ratio will be amplified when increasing the pile number.

The comparison between settlement ratios obtained by the tests and Randolph's formula shown in Fig. 8 informs that, the variation rule of these ratios when changing the spacing and the pile length of the two methods are quite similar. However, the settlement ratios found experimentally are larger than the corresponding value calculated by the formula for all studied pile groups.
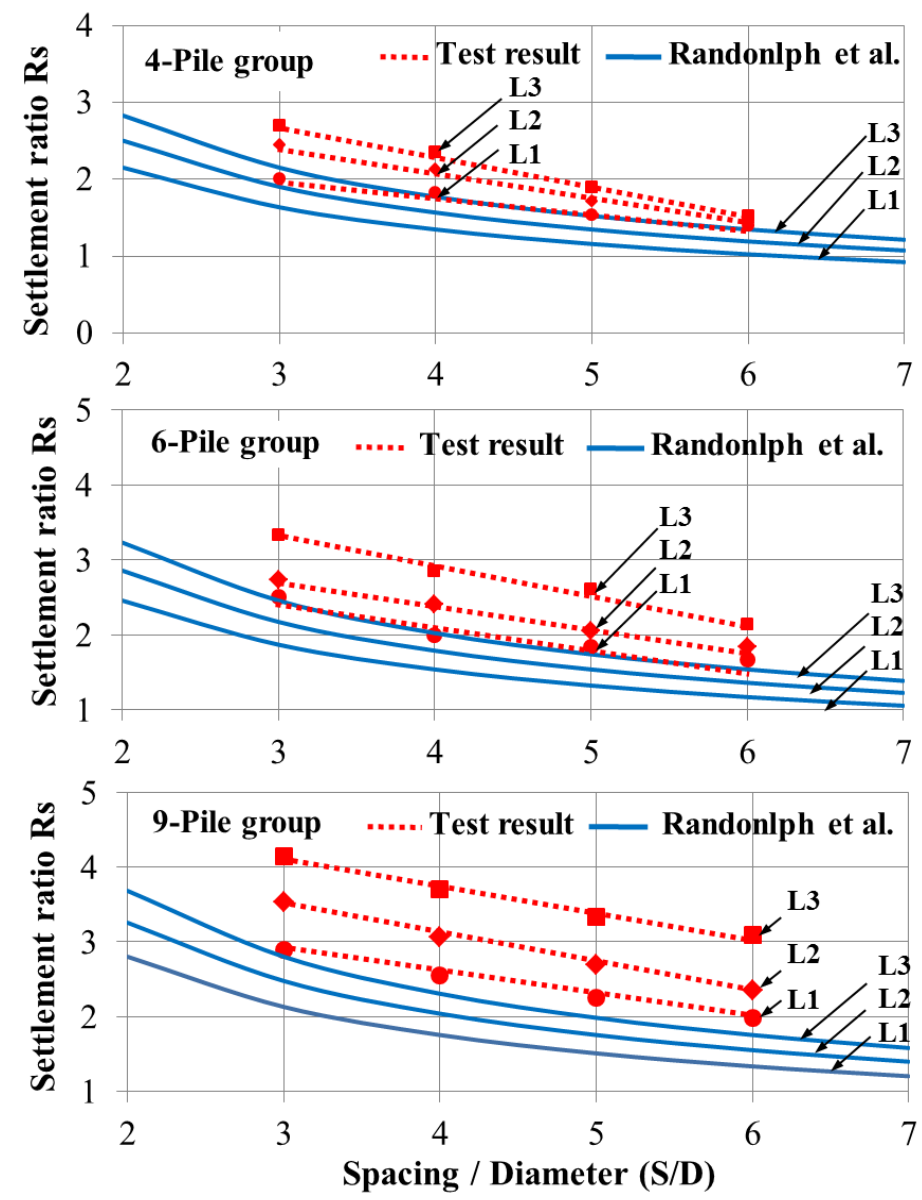

Figure 8 . The settlement ratios calculated by Randolph's formula and tested results.

\subsection{Load distribution per pile}

The modulus of the pile material $\left(E_{p}\right)$ is used to convert strain gauges data into the load distribution along a pile:

$$
Q_{\mathrm{i}}=\varepsilon_{\mathrm{i}} \times E_{\mathrm{p}} \times A
$$

Where: $Q_{i}$ and $\varepsilon_{1}$ are the load distribution and strain at level $i$ of a pile respectively, and $A$ is the cross sectional area of the pile. 
Transport and Communications Science Journal, Vol. 72, Issue 1 (01/2021), 84-94

The pile head load at the maximum group load used to estimate the pile efficiency $\left(e_{i}\right)$ is shown in Tab.1. It can be seen that in 6-pile and 9-pile groups the pile efficiency decreases markedly in order of corner, edge, and centre piles. Also, the data in Tab.1 point out that the pile spacing has more affected than that of pile length on the value of efficiency.

Table 1 . The efficiency of each pile position in the studied pile groups.

\begin{tabular}{|c|c|c|c|c|c|c|c|c|c|c|}
\hline \multirow{3}{*}{$\begin{array}{l}\text { Pile } \\
\text { group }\end{array}$} & \multirow{3}{*}{$\begin{array}{c}\text { Pile } \\
\text { spacing } \\
(\mathrm{S})\end{array}$} & \multicolumn{9}{|c|}{ Pile efficiency: $e_{\mathrm{i}}=\mathrm{Q}_{0} / \mathrm{Q}_{\mathrm{S}}$} \\
\hline & & \multicolumn{3}{|c|}{ Ratio of $\mathrm{L} / \mathrm{D}=\mathbf{2 0}$} & \multicolumn{3}{|c|}{ Ratio of $L / D=25$} & \multicolumn{2}{|c|}{ Ratio of $\mathrm{L} / \mathrm{D}=\mathbf{3 0}$} & \multirow[b]{2}{*}{$\begin{array}{c}\text { Centre } \\
\text { pile }\end{array}$} \\
\hline & & $\begin{array}{l}\text { Corner } \\
\text { pile }\end{array}$ & $\begin{array}{c}\text { Edge } \\
\text { pile }\end{array}$ & $\begin{array}{l}\text { Centre } \\
\text { pile }\end{array}$ & $\begin{array}{l}\text { Corner } \\
\text { pile }\end{array}$ & $\begin{array}{c}\text { Edge } \\
\text { pile }\end{array}$ & $\begin{array}{l}\text { Centre } \\
\text { pile }\end{array}$ & $\begin{array}{c}\text { Corner } \\
\text { pile }\end{array}$ & $\begin{array}{l}\text { Edge } \\
\text { pile }\end{array}$ & \\
\hline \multirow{4}{*}{$\begin{array}{l}\text { 4-pile } \\
\text { group }\end{array}$} & $\mathrm{S}=3 \mathrm{D}$ & 0.90 & - & - & 0.89 & - & - & 0.87 & - & - \\
\hline & $S=4 D$ & 0.92 & - & - & 0.91 & - & - & 0.89 & - & - \\
\hline & $S=5 D$ & 0.94 & - & - & 0.93 & - & - & 0.90 & - & - \\
\hline & $S=6 D$ & 0.97 & - & - & 0.95 & - & - & 0.94 & - & - \\
\hline \multirow{4}{*}{$\begin{array}{l}\text { 6-pile } \\
\text { group }\end{array}$} & $S=3 D$ & 0.78 & 0.65 & - & 0.77 & 0.64 & - & 0.76 & 0.63 & - \\
\hline & $S=4 D$ & 0.82 & 0.70 & - & 0.79 & 0.68 & - & 0.78 & 0.65 & - \\
\hline & $S=5 D$ & 0.84 & 0.74 & - & 0.82 & 0.72 & - & 0.81 & 0.71 & - \\
\hline & $S=6 D$ & 0.88 & 0.81 & - & 0.86 & 0.78 & - & 0.84 & 0.76 & - \\
\hline \multirow{4}{*}{$\begin{array}{l}\text { 9-pile } \\
\text { group }\end{array}$} & $\mathrm{S}=3 \mathrm{D}$ & 0.74 & 0.60 & 0.36 & 0.74 & 0.59 & 0.34 & 0.73 & 0.58 & 0.31 \\
\hline & $S=4 D$ & 0.79 & 0.66 & 0.42 & 0.77 & 0.63 & 0.40 & 0.76 & 0.63 & 0.38 \\
\hline & $S=5 D$ & 0.83 & 0.70 & 0.47 & 0.81 & 0.68 & 0.45 & 0.80 & 0.66 & 0.42 \\
\hline & $S=6 D$ & 0.85 & 0.77 & 0.56 & 0.84 & 0.75 & 0.52 & 0.82 & 0.73 & 0.50 \\
\hline
\end{tabular}

Note: $Q_{0}$ is the pile head load conducted at the maximum group load and $Q_{S}$ is the bearing capacity of a single pile having the same length.

The data in Tab.2 shows that in a group with the same number and spacing of pile the total pile toe load rises distinctly when the pile length increasing. This provides more evidence to suggest that the pile length is one of the important factors affecting the group settlement ratio because the toe resistance is the primary reason causing the movement of the piles under vertical load.

Table 2. The percentage of total pile toe load of the studied pile groups.

\begin{tabular}{cccccccccc}
\hline \hline \multirow{2}{*}{$\begin{array}{c}\text { Pile } \\
\text { spacing } \\
(\mathrm{S})\end{array}$} & \multicolumn{6}{c}{ Percentage of toe resistance: $e_{\mathrm{b}}(\%)=\sum\left(\mathrm{Q}_{\mathrm{b}}^{\mathrm{i}} \times 100\right) / \mathrm{Q}_{\mathrm{G}}$} \\
\cline { 2 - 11 } & \multicolumn{3}{c}{ 4-pile group } & \multicolumn{5}{c}{ 6-pile group } & \multicolumn{4}{c}{ 9-pile group } \\
\cline { 2 - 11 } & $\mathrm{L} / \mathrm{D}=20$ & $\mathrm{~L} / \mathrm{D}=25$ & $\mathrm{~L} / \mathrm{D}=30$ & $\mathrm{~L} / \mathrm{D}=20$ & $\mathrm{~L} / \mathrm{D}=25$ & $\mathrm{~L} / \mathrm{D}=30$ & $\mathrm{~L} / \mathrm{D}=20$ & $\mathrm{~L} / \mathrm{D}=25$ & $\mathrm{~L} / \mathrm{D}=30$ \\
\hline $\mathbf{S = 3 D}$ & 14.73 & 16.23 & 17.56 & 10.01 & 13.12 & 16.43 & 8.41 & 11.08 & 15.73 \\
$\mathbf{S = 4 D}$ & 15.12 & 16.78 & 17.94 & 10.56 & 13.89 & 16.88 & 8.91 & 11.32 & 16.09 \\
$\mathbf{S = 5 D}$ & 15.44 & 17.09 & 18.21 & 11.47 & 14.38 & 17.21 & 9.12 & 12.36 & 16.67 \\
$\mathbf{S = 6 D}$ & 16.28 & 17.22 & 18.69 & 12.18 & 15.06 & 17.67 & 9.73 & 12.69 & 17.02 \\
\hline \hline
\end{tabular}


Transport and Communications Science Journal, Vol. 72, Issue 1 (01/2021), 84-94

In which: $\sum \mathrm{Q}_{\mathrm{b}}^{\mathrm{i}}$ is the total of all pile toe load in a pile group obtained at the maximum group load, and $Q_{G}$ is the maximum group load.

\section{CONCLUSION}

A small-scale load testing program was carried out on the single piles and pile groups installed in soft clay soil. Based on the analysis of the experimental results, the following conclusions can be reached:

- The pile number is the prime factor influenced the group efficiency $(\eta)$. Besides that, for the investigated pile groups, the group effect was more pronounced for pile spacing of $3 \mathrm{D}$ than for remaining spacing, showing that the impact of the pile spacing is greater than that of the pile length on the group capacity. For a pile group using the pile spacing of $3 \mathrm{D}$ or $4 \mathrm{D}$, Feld's rule can be applied to estimate the pile group efficiency.

- The settlement ratio $\left(R_{S}\right)$ of the studied pile groups tended to increase rapidly with the pile number and pile length. Almost all of the settlement ratios conducted experimentally were higher than those of predicted by Randolph's formula. These values of the investigated 9-pile groups are quite large, ranging from 1.98 to 4.14. Therefore, when designing the pile foundations consisted of many piles, care should be taken to choose the ultimate settlement value to determine the bearing capacity of the single pile based on the pile load test. The empirical expression of Randolph and Clancy (1993) is useful to determine the settlement ratio of a pile group with a pile length/diameter ratio of 20.

- The efficiencies of the side and centre piles in the studied pile groups are smaller significantly than those of the corner piles, and they fluctuated in a range of 0.58 to 0.81 , and 0.31 through 0.56 , respectively. Therefore, to optimize the working ability of a pile group, it is possible to use a group with different pile lengths.

\section{REFERENCES}

[1]. T. W. Adejumo, I. L. Boiko, Modeling of Axially Loaded Pile Group Settlement in Soft Compressive Clay, International Journal of Remote Sensing \& Geoscience, 2 (2013) 98-103. http://www.ijrsg.com/Files/adffcb11-c2d0-43b8-8cc4-6573683ecc2d IJRSG 06 15.pdf

[2]. M.S. Sayed, R. M. Bakeer, Efficiency formula for pile groups. Journal of Geotechnical Engineering, 118 (1992) 278-299. https://doi.org/10.1061/(ASCE)0733-9410(1992)118:2(278)

[3]. J. Garnier et al., Catalogue of scaling laws and similitude questions in Geotechnical cetrifuge modeling, International Journal of Physical Modelling in Geotechnics, 3 (2007) 1-23. https://doi.org/10.13140/2.1.1615.3281

[4]. S. Goto, S. Aoyama, B. Liu, I. Towhata, A. Akita, A.A. Renzo, Model loading tests in large soil tank on group behavior of pies, Proceeding of the $18^{\text {th }}$ International Conference on Soil Mechanics and Geotechnical Engineering, Paris 2013. pp 2731-2734.

[5]. Y. Koizumi, K. Ito, Field tests with regard to pile driving and bearing capacity of piled foundation, Soil and Foundation, 7 (1967) 30-53. https://doi.org/10.3208/sandf1960.7.3_30

[6]. Z. You, Y. Chen, The Use of Tactile Sensors and PIV Anlysis for Understanding the Bearing Mechanism of Pile Group Sensor, 18 (2018) 472. https://doi.org/10.3390/s18020476

[7]. P. Kytiyodom et al., Influence of reaction piles on the behaviour of a test pile in stactic load testing, Canadian Geotechnical Journal, 41 (2004) 408-420. https://doi.org/10.1139/t03-098

[8]. K. Horikoshi, M. F. Randolph, Estimation of overall settlement of piled rafts, Soil and foundation 
Transport and Communications Science Journal, Vol. 72, Issue 1 (01/2021), 84-94

39 (1999) 59-68. https://doi.org/10.3208/sandf.39.2_59

[9]. J. D. Patil et al., An experiment study on behavior of piled raft foundation, Indian Geotechnical Journal, 46 (2016) 16-24. https://doi.org/10.1007/s40098-015-0145-7

[10]. A. B. Vesic, Bearing Capacity of Deep Foundations in Sand. Committee on Stress Distribution in Earth Masses, (1963) 112-153. http://onlinepubs.trb.org/Onlinepubs/hrr/1963/39/39-007.pdf

[11]. T. Whitaker, Experiments with Model Piles in Groups, Geotechnique, 7 (1957) 147-167. https://doi.org/10.1680/geot.1957.7.4.147

[12]. Y. Zhang et al., Load test on Full- scale bored pile groups, Proceeding of the $18^{\text {th }}$ International Conference on Soil Mechanics and Geotechnical Engineering, Paris, 2013, pp. 2909-2912. https://www.cfms-sols.org/sites/default/files/Actes/2909-2912.pdf 